\title{
LOS ARTEFACTOS DE LA LUZ, PERPLEJOS
}

\section{Jenaro TALENS}

Nunca hice pactos con mis ojos.

Permití que el afuera me inundase

y que auroras y noches, sin distinción, abriesen

puerta a los avatares de la irrealidad.

Hoy, cuando ya la nieve de los años

ha cuajado en mis venas, observo alrededor

cómo transcurre el tiempo sin que en él habiten

otros misterios diferentes.

Ahora ya sé que la mirada sola

no siempre basta para comprender.

\section{II}

No convoco a la muerte cuando digo

que este otoño inestable a flor de piel se nutre de palabras nacidas en el cielo de mi boca. ¿Soy yo quien busca, entre los huecos calcinados,

a quien una vez fui? Sus huellas y el asombro

de caminar ligero de equipaje

no me acompañan ya y la ineludible

serenidad de sus atardeceres

no dan razón del resplandor caduco

con que se anuncian puertos y fronteras.

Ni lo que dije, ni lo que callé dibujan 
el rumbo inquebrantable del azar. Tampoco

forman ya parte del sentido.

El animal que viene de la sombra

sabe de biografías llenas de crepúsculos

que arden en las hogueras de la madrugada.

Reconocido, al fin, en mi silencio,

me resisto a seguir el rastro de su voz.

Mientras, en el calor de las cenizas,

siembro murmullos que heredé, la sola

e imperceptible música que ofrece

tu transparencia, sol, tu transparencia. 